\title{
Otomasi Perencanaan Produksi Pada Sekolah
}

\author{
Dwi Haris Sanjaya', Yoga Firmansyah ${ }^{2}$, Moch. Irsyadul Anam ${ }^{3}$, M. Ainul Yaqin ${ }^{4}$ \\ Sains dan Teknologi, Univeritas Islam Negeri Maulana Malik Ibrahim Malang \\ Jl. Gajayana 50 Malang 65144, Telp: (0341) 551354 \\ 116650084@student.uin-malang.ac.id,216650077@student.uin-malang.ac.id, \\ 316650119@student.uin-malang.ac.id, 4 yaqinov@ti.uin-malang.ac.id
}

\begin{abstract}
Production planning is very important in business processes. Production planning aims to minimize the total cost of production. In this research, automation of production planning is done using data obtained based on school business processes. The purpose of this study is to determine the best production costs for the smooth production process of schools. This research uses descriptive research. Descriptive research aims to obtain information in the implementation of school business process planning. The calculation of production costs in this study uses the Activity Based Costing $(A B C)$ technique and is carried out using Microsoft Excel. The calculation of this research is done by first determining the total target and raw materials from the school production process, then calculating the production costs of this school production process. The results of these calculations found that the optimal production cost for each student of a total of 300 students during the 3-year learning period is Rp. 605,728. From this study, it is also known that the total number of students and labor directly affects the amount of production costs.
\end{abstract}

Keywords: Automation, Production Planing, School, ERP

\begin{abstract}
Abstrak
Perencanaan produksi sangat penting dalam proses bisnis. Perencanaan produksi bertujuan untuk meminimalkan total biaya produksi. Pada penelitian ini dilakukan otomasi perencanaan produksi menggunakan data yang didapat berdasarkan proses bisnis sekolah. Tujuan dari penelitian ini adalah untuk mengetahui biaya produksi terbaik bagi kelancaran proses produksi sekolah. Penelitian ini menggunakan penelitian deskriptif. Penelitian deskriptif bertujuan untuk memperoleh informasi dalam pelaksanaan perencanaan proses bisnis sekolah. Perhitungan biaya produksi pada penelitian ini menggunakan teknik Activity Based Costing (ABC) dan dilakukan dengan menggunakan Microsoft Excel. Perhitungan penelitian ini dilakukan dengan terlebih dahulu menentukan total target dan bahan baku dari proses produksi sekolah, kemudian dihitung biaya produksi proses produksi sekolah ini. Hasil dari perhitungan tersebut ditemukan bahwa biaya produksi yang optimal untuk setiap siswa dari total 300 siswa selama masa 3 tahun pembelajaran adalah Rp. 605.728. Dari penelitian ini juga diketahui bahwa jumlah dari total siswa dan tenaga kerja mempengaruhi jumlah biaya produksi secara langsung
\end{abstract}

Kata kunci: Otomasi, Perencanaan Produksi, Sekolah, ERP

\section{PENDAHULUAN}

Sekolah merupakan sebuah organisasi (enterprise) dibidang pendidikan. Sebagai enterprise dibidang pendidikan, untuk melakukan produksi sekolah membutuhkan sebuah perencanaan produksi. Perencanaan produksi merupakan kegiatan merencanakan apa yang dilakukan sebelum melakukan kegiatan produksi dalam satu periode produksi [1].

Perencanaan produksi merupakan perencanaan tentang produk apa dan berapa yang akan diproduksi oleh pengusaha yang bersangkutan dalam satu periode yang akan datang. Menurut KBBI perencanaan merupakan suatu proses, cara atau perbuatan yang merencanakan (merancangkan), sedangkan produksi 
adalah sebuah proses untuk mengeluarkan hasil (produk). Perencanaan produksi merupakan kegiatan merencanakan apa yang akan dilakukan sebelum melakukan kegiatan produksi dengan mempertimbangkan target produksi, biaya produksi dan sumber daya yang dimiliki [2].

Perencanaan produksi juga dapat dinyatakan sebagai penentuan tingkat kemampuan produksi dari suatu enterprise. Perencanaan produksi merupakan bagian dari rencana strategi enterprise yang berhubungan harmonis dengan perencanaan bisnis (business planning) dan perencanaan pemasaran (marketing planning). Perencanaan produksi dapat juga diartikanebagai proses merencakan jumlah produksi, persediaan, dan workforce level untuk memenuhi target produksi [3]. Perencanaan produksi dapat terlaksana dengan dukungan pengambilan keputusan yang tepat. Pengambilan yang dimaksud disini adalah menetapkan jumlah produksi, biaya produksi dan sumber daya yang dibutuhkan.[4] Dalam perencanaan produksi penentuan jumlah optimal produk, biaya produksi dan sumber daya yang diperlukan merupakan kunci bagi perencanaan produksi yang tepat.

Terdapat beberapa masalah dalam perencanaan produksi sekolah yaitu, dalam melakukan perencanaan produksi masih dilakukan dengan manual yang kurang efektif sehingga masih ada beberapa sekolah yang belum bisa membuat RAB (Rancangan Anggaran Belanja). Selain itu masih ada sekolah-sekolah yang transparasi anggaran dan akuntabilitasnya minim. Hal ini dapat menyebabkan proses produksi tidak efektif atau bisa jadi mengalami kegagalan. Untuk mengatasi hal tersebut maka dibutuhkan sebuah perencanaan produksi. Penelitian ini bertujuan untuk mengatasi perencanaan produksi yang kurang efektif dengan mengotomasikan perencanaan produksi tersebut. Perhitungan pada penelitian ini menerapkan teknik Activity Based Costing (ABC). Teknik ABC adalah pendekatan perhitungan biaya produk dengan membebankan biaya ke produk berdasarkan biaya konsumsi sumber daya oleh aktivitas [5]. Otomasi perencanaan produksi dapat dilakukan dengan menggunakan aplikasi Microsoft Excel. Sehingga meningkatkan efektifitas dan efisiensi perencanaan produksi yang dilakukan. Otomasi sendiri merupakan penerapan teknologi untuk menjalankan tugas secara otomatis yang bertujuan untuk meningkatkan kecepatan, keefektifan dan ketelitian [6].

\section{METODOLOGI PENELITIAN}

Penelitian ini merupakan penelitian deskriptif, yang bertujuan untuk memperoleh informasi dalam pelaksanaan perencanaan proses bisnis sekolah. Aspek yang akan dinilai meliputi:

a. Pengelolaan Administrasi Sekolah.

b. Pelaksanaan Pembelajaran/praktik pada sekolah.

c. Pencapaian Tujuan sekolah.

d. Faktor pendukung dan penghambat dalam pelaksanaan kegiatan sekolah.

Metode yang digunakan untuk memperoleh data sebagaimana yang diinginkan dalam penelitian ini, yaitu dengan metode angket dan wawancara 
angket. Terdapat 5 langkah dalam melakukan penelitian ini seperti pada gambar dibawah:

1. Penentuan Jumlah Data yang akan diproduksi. Pada perencanaan ini kita akan memproduksi lulusan sebanyak 100 siswa

2. Menentukan jumlah material yang di selama proses produksi

3. Menghitung harga dari setiap material yang digunakan selama proses produksi

4. Menghitung biaya produksi setiap produk (dalam kasus ini setiap siswa)

5. Mengetahui hasil perhitungan

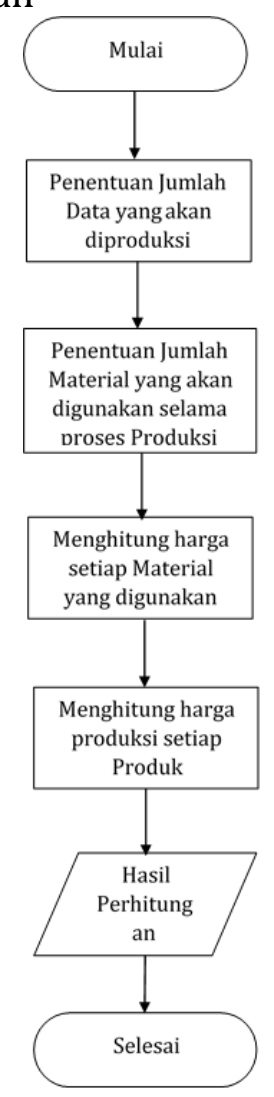

Gambar 1. Flowchart penelitian

\section{HASIL DAN PEMBAHASAN}

Untuk memproduksi lulusan sejumlah 100 siswa, dibutuhkan sub sistem input dan sarana produksi. Dalam produksi pada sekolah input dan sarana yang harus diperhatikan adalah bangunan, sarana prasarana, guru, buku pelajaran, dan kegitan pendukung sekolah. Dari hal tersebut maka dapat digambarkan bahwa setiap siswa membutuhkan hal-hal sebagai berikut: 
Jurnal Riset Sistem Informasi Dan Teknik Informatika (JURASIK)

Volume 5 Nomor 1 Februari, pp 68-76

ISSN: 2527-5771/EISSN: 2549-7839

http://tunasbangsa.ac.id/ejurnal/index.php/jurasik

Tabel 1. Tabel Kebutuhan Produksi

\begin{tabular}{|c|c|c|c|c|c|c|}
\hline NIS & Nama Siswa & \multicolumn{4}{|c|}{ Kebutuhan Produksi } & $\begin{array}{l}\text { Jangka } \\
\text { Waktu }\end{array}$ \\
\hline 19001 & $A$ & \multicolumn{4}{|c|}{ Sarpras, Guru, Bangunan, Buku Pelajaran, Biaya Operasional } & 3 tahun \\
\hline 19002 & $\mathrm{~B}$ & \multicolumn{4}{|c|}{ Sarpras, Guru, Bangunan, Buku Pelajaran, Biaya Operasional } & 3 tahun \\
\hline 19003 & C & \multicolumn{4}{|c|}{ Sarpras, Guru, Bangunan, Buku Pelajaran, Biaya Operasional } & 3 tahun \\
\hline 19004 & $\mathrm{D}$ & \multicolumn{4}{|c|}{ Sarpras, Guru, Bangunan, Buku Pelajaran, Biaya Operasional } & 3 tahun \\
\hline 19005 & $\mathrm{E}$ & \multicolumn{4}{|c|}{ Sarpras, Guru, Bangunan, Buku Pelajaran, Biaya Operasional } & 3 tahun \\
\hline 19006 & $\mathrm{~F}$ & \multicolumn{4}{|c|}{ Sarpras, Guru, Bangunan, Buku Pelajaran, Biaya Operasional } & 3 tahun \\
\hline 19007 & G & \multicolumn{4}{|c|}{ Sarpras, Guru, Bangunan, Buku Pelajaran, Biaya Operasional } & 3 tahun \\
\hline 19008 & $\mathrm{H}$ & \multicolumn{4}{|c|}{ Sarpras, Guru, Bangunan, Buku Pelajaran, Biaya Operasional } & 3 tahun \\
\hline 19009 & 1 & \multicolumn{4}{|c|}{ Sarpras, Guru, Bangunan, Buku Pelajaran, Biaya Operasional } & 3 tahun \\
\hline 19010 & $\mathrm{~J}$ & \multicolumn{4}{|c|}{ Sarpras, Guru, Bangunan, Buku Pelajaran, Biaya Operasional } & 3 tahun \\
\hline$\ldots$ & $\ldots$ & $\ldots$ & $\ldots$ & $\ldots$ & $\ldots$ & $\ldots$ \\
\hline
\end{tabular}

Setelah diketahui beberapa kebutuhan produksi yang dibutuhkan, kemudian dijabarkan harga dari setiap kebutuhan

Tabel 2. Biaya Sarana Prasarana

\begin{tabular}{|c|c|lr|lr|}
\hline No & Jenis & \multicolumn{2}{|c|}{ Biaya Satuan } & \multicolumn{2}{c|}{ Total Biaya } \\
\hline 1 & Kursi siswa & $\mathrm{Rp}$ & 215.000 & $\mathrm{Rp}$ & 12.900 .000 \\
\hline 2 & Meja siswa & $\mathrm{Rp}$ & 300.000 & $\mathrm{Rp}$ & 18.000 .000 \\
\hline 3 & Kursi Guru & $\mathrm{Rp}$ & 300.000 & $\mathrm{Rp}$ & 1.200 .000 \\
\hline 4 & Meja Guru & $\mathrm{Rp}$ & 375.000 & $\mathrm{Rp}$ & 1.500 .000 \\
\hline 5 & Lemari & $\mathrm{Rp}$ & 425.000 & $\mathrm{Rp}$ & 796.875 \\
\hline 6 & Papan panjang & $\mathrm{Rp}$ & 160.000 & $\mathrm{Rp}$ & 300.000 \\
\hline 7 & Papan tulis & $\mathrm{Rp}$ & 556.000 & $\mathrm{Rp}$ & 1.042 .500 \\
\hline 8 & Tempat Sampah & $\mathrm{Rp}$ & 20.000 & $\mathrm{Rp}$ & 37.500 \\
\hline 9 & Tempat cuci tangan & $\mathrm{Rp}$ & 350.000 & $\mathrm{Rp}$ & 656.250 \\
\hline 10 & Jam dinding & $\mathrm{Rp}$ & 35.000 & $\mathrm{Rp}$ & 65.625 \\
\hline 11 & Soket listrik & $\mathrm{Rp}$ & 15.000 & $\mathrm{Rp}$ & 28.125 \\
\hline 12 & Listrik PLN & $\mathrm{Rp}$ & 500.000 & $\mathrm{Rp}$ & 500.000 \\
\hline 13 & Lampu & $\mathrm{Rp}$ & 60.000 & $\mathrm{Rp}$ & 2.250 .000 \\
\hline \multicolumn{7}{c}{} & $\mathrm{Rp}$ & 36.526 .875 \\
\hline
\end{tabular}

Diketahui bahwa harga kursi dipasaran seharga Rp. 215.000 dengan batas maksimum pakai selama 5 tahun. Maka dari itu biaya untuk pengadaan kursi adalah Harga kursi satuan dikalikan jumlah siswa dibagi dengan Batas maksimum pakai. Sehingga :

$$
\begin{gathered}
\text { Total }=(215.000 * 300) / 5 \\
\text { Total }=\text { Rp. } 12.900 .000
\end{gathered}
$$

Untuk biaya pengadaan sarana prasarana yang lainnya dapat menggunakan metode penghitungan seperti yang diatas. Kemudian kita jumlah semua biaya pengadaan per unit sehingga didapatkan hasil seperti pada Tabel 2 Maka didapat rumus sebagai berikut : 
Jurnal Riset Sistem Informasi Dan Teknik Informatika (JURASIK)

Volume 5 Nomor 1 Februari, pp 68-76

ISSN: 2527-5771/EISSN: 2549-7839

http://tunasbangsa.ac.id/ejurnal/index.php/jurasik

\section{Biaya $=\sum \frac{\text { Harga unit satuan x Jumlah Siswa }}{\text { Batas maksimum pakai }}$}

Tabel 3. Biaya Guru dan SDM

\begin{tabular}{|c|c|c|c|c|c|c|c|c|}
\hline No & Jabatan & & Mapel & Tunjangan & Tarif per Jam & Gaji & Jumlah Guru & Total \\
\hline 1 & Kepala Sekolah & - & - & Rp 1.000 .000 & Rp 100.000 & Rp 3.000.000 & 1 & Rp 3.000 .000 \\
\hline 2 & Bag. Kurikulum & - & - & - & Rp 50.000 & Rp 1.000.000 & 1 & Rp 1.000 .000 \\
\hline 3 & Bag. Kesiswaan & Pembina Osis & - & - & Rp 50.000 & Rp 1.000 .000 & 1 & Rp 1.000 .000 \\
\hline 4 & & Pembina Ekstra & - & - & Rp 50.000 & Rp 1.000 .000 & 1 & Rp 1.000 .000 \\
\hline 5 & Bag. Sarana Prasarana & & - & - & Rp 50.000 & Rp 1.000 .000 & 1 & \begin{tabular}{|ll}
$\operatorname{Rp}$ & 1.000 .000 \\
\end{tabular} \\
\hline 6 & Bag. Humas & KORPRI & - & - & Rp 50.000 & Rp 1.000.000 & 1 & Rp 1.000 .000 \\
\hline 7 & & PGR & - & - & Rp 50.000 & Rp 1.000 .000 & 1 & $\operatorname{Rp} 1.000 .000$ \\
\hline 8 & & UKS & - & - & Rp 50.000 & Rp 1.000 .000 & 1 & Rp 1.000 .000 \\
\hline 9 & & Koperasi & - & - & Rp 50.000 & Rp 1.000 .000 & 1 & Rp 1.000 .000 \\
\hline 10 & Kordinator BK & & - & - & Rp 50.000 & Rp 1.000 .000 & 1 & Rp 1.000 .000 \\
\hline 11 & Pendidik & Guru & Pendidikan Agama & - & Rp 50.000 & Rp 1.250 .000 & 3 & $\operatorname{Rp} \quad 3.750 .000$ \\
\hline 12 & Pendidik & Guru & Pendidikan Kwn & - & Rp 50.000 & Rp 1.250.000 & 1 & Rp 1.562 .500 \\
\hline 13 & Pendidik & Guru & Bahasa Indonesia & - & Rp 50.000 & Rp 2.500 .000 & 3 & $\operatorname{Rp} \quad 6.250 .000$ \\
\hline 14 & Pendidik & Guru & Bahasa Inggris & - & Rp 50.000 & Rp 2.500 .000 & 3 & Rp 6.250 .000 \\
\hline 15 & Pendidik & Guru & Matematika & - & Rp 50.000 & Rp 2.500 .000 & 3 & Rp 6.250 .000 \\
\hline 16 & Pendidik & Guru & IImu Pengetahuan Alam & - & Rp 50.000 & Rp 2.500 .000 & 3 & Rp 6.250 .000 \\
\hline 17 & Pendidik & Guru & IImu Pengetahuan Sosial & - & Rp 50.000 & Rp 2.500 .000 & 3 & Rp 6.250 .000 \\
\hline 18 & Pendidik & Guru & Seni Budaya & - & Rp 50.000 & Rp 1.250 .000 & 1 & $\operatorname{Rp} \quad 1.562 .500$ \\
\hline 19 & Pendidik & Guru & Penjaskes & - & Rp 50.000 & Rp 1.250.000 & 3 & $\operatorname{Rp} \quad 3.750 .000$ \\
\hline 20 & Pendidik & Guru & Ketrampilan / TIK & - & Rp 50.000 & Rp 1.250 .000 & 3 & Rp 3.750 .000 \\
\hline 21 & Pendidik & Guru & Muatan Lokal & - & Rp 50.000 & Rp 1.250 .000 & 3 & $\operatorname{Rp} \quad 3.750 .000$ \\
\hline & \multicolumn{7}{|c|}{ Total } & Rp 61.375 .000 \\
\hline
\end{tabular}

Untuk biaya Guru dan SDM yang ada di sekolah kita menggunakan cara sebagai berikut :

$$
\text { Total }=\sum \mathrm{Tj}+(\text { Bpj } \mathrm{x} J \mathrm{~m})
$$

Dimana Tj merupakan biaya tunjangan yang diberikan sekolah kepada setiap jabatan yang ada disekolah, Bpj merupakan Tarif per jam, dan Jm merupakan jumlah jam mengajar

Tabel 4. Biaya Gedung

\begin{tabular}{|c|c|c|c|c|c|}
\hline No & Nama & \multicolumn{2}{|c|}{ Biaya Satuan } & \multicolumn{2}{|c|}{ Total Biaya } \\
\hline 1 & Gedung Kelas $(7 \times 8)$ & $\mathrm{Rp}$ & 115.000 .000 & $\mathrm{Rp}$ & 1.078 .125 .000 \\
\hline 2 & Gedung Olahraga & $\mathrm{Rp}$ & 100.000 .000 & $\mathrm{Rp}$ & 100.000 .000 \\
\hline 3 & Gedung Lab $(3.5 \times 4)$ & $\mathrm{Rp}$ & 67.392 .000 & $\mathrm{Rp}$ & 67.392 .000 \\
\hline 4 & Mushola ( 2 x 2.5$)$ & $\mathrm{Rp}$ & 39.638 .000 & $\mathrm{Rp}$ & 39.638 .000 \\
\hline 5 & Toilet & $\mathrm{Rp}$ & 30.000 .000 & $\mathrm{Rp}$ & 90.000 .000 \\
\hline 6 & Kantin & $\mathrm{Rp}$ & 20.000 .000 & $\mathrm{Rp}$ & 20.000 .000 \\
\hline 7 & Perpustakaan & $\mathrm{Rp}$ & 30.000 .000 & $\mathrm{Rp}$ & 30.000 .000 \\
\hline 8 & Aula & $\mathrm{Rp}$ & 50.000 .000 & $\mathrm{Rp}$ & 50.000 .000 \\
\hline \multicolumn{4}{|c|}{ Total Biaya } & $\mathrm{Rp}$ & 1.285 .155 .000 \\
\hline
\end{tabular}

Sama seperti perhitungan Biaya sarana prasarana, untuk menghitung biaya gedung sekolah kita menggunakan rumus : 
Total Biaya $=\sum \frac{\text { BB x JB }}{\text { BMP }}$

Dimana BB merupakan biaya untuk membangun sebuah gedung, JB merupakan jumlah gedung yang dibangun, dan BMP adalah batas waktu penggunaan sebuah gedung.

Tabel 5. Biaya Buku per Semester

\begin{tabular}{|c|c|c|c|c|c|}
\hline No & Mata Pelajaran & \multicolumn{2}{|c|}{ Biaya Per Murid } & \multicolumn{2}{|c|}{ Total Biaya } \\
\hline 1 & Pendidikan Agama & $\mathrm{Rp}$ & 100.000 & $\mathrm{Rp}$ & 30.000 .000 \\
\hline 2 & Pendidikan Kwn & $\mathrm{Rp}$ & 100.000 & $\mathrm{Rp}$ & 30.000 .000 \\
\hline 3 & Bahasa Indonesia & $\mathrm{Rp}$ & 100.000 & $\mathrm{Rp}$ & 30.000 .000 \\
\hline 4 & Bahasa Inggris & $\mathrm{Rp}$ & 100.000 & $\mathrm{Rp}$ & 30.000 .000 \\
\hline 5 & Matematika & $\mathrm{Rp}$ & 100.000 & $\mathrm{Rp}$ & 30.000 .000 \\
\hline 6 & Ilmu Pengetahuan Alam & $\mathrm{Rp}$ & 100.000 & $\mathrm{Rp}$ & 30.000 .000 \\
\hline 7 & Ilmu Pengetahuan Sosial & $\mathrm{Rp}$ & 100.000 & $\mathrm{Rp}$ & 30.000 .000 \\
\hline 8 & Seni Budaya & $\mathrm{Rp}$ & 100.000 & $\mathrm{Rp}$ & 30.000 .000 \\
\hline 9 & Penjaskes & $\mathrm{Rp}$ & 100.000 & $\mathrm{Rp}$ & 30.000 .000 \\
\hline 10 & Ketrampilan / TIK & $\mathrm{Rp}$ & 100.000 & $\mathrm{Rp}$ & 30.000 .000 \\
\hline 11 & Muatan Lokal & $\mathrm{Rp}$ & 100.000 & $\mathrm{Rp}$ & 30.000 .000 \\
\hline \multicolumn{4}{|c|}{ Total Biaya } & $\mathrm{Rp}$ & 330.000 .000 \\
\hline
\end{tabular}

Untuk perhitungan biaya buku berbeda dengan biaya penghitungan biaya sarpras dan gedung. Dikarenakan buku ini merupakan bahan baku habis pakai, maka biayanya langsung dibebankan kepada siswa. Untuk menghitung biaya pengadaan buku digunakan rumus sebagai berikut :

Total $=\sum$ (Harga satuan buku $\mathrm{x}$ jumlah siswa)

Setelah diketahui semua total harga buku satuan, kemudian dijumlahkan untuk mengetahui total biaya pengadaan buku siswa selama satu semester.

Tabel 6. Biaya Operasional Pembangunan Sekolah

\begin{tabular}{|c|c|c|c|c|c|c|c|c|}
\hline \multirow{2}{*}{$\begin{array}{c}\text { No } \\
1 \\
\end{array}$} & \multirow{2}{*}{$\frac{\text { Nama Kegiatan }}{\text { Biaya Pengadaan Buku }}$} & \multirow[b]{2}{*}{ Transport } & \multicolumn{2}{|c|}{ Tarif } & \multicolumn{2}{|c|}{ Biaya Total } & \multicolumn{2}{|c|}{ Total Sampai Lulus } \\
\hline & & & $\mathrm{Rp}$ & 15.000 & $\mathrm{Rp}$ & 15.000 & $\mathrm{Rp}$ & 90.000 \\
\hline & & Uang Makan & $\mathrm{Rp}$ & 10.000 & Rp & 10.000 & $\mathrm{Rp}$ & 60.000 \\
\hline \multirow[t]{7}{*}{2} & Ujian & Biaya Pe mbuatan Soal & $\mathrm{Rp}$ & 50.000 & $\mathrm{Rp}$ & 50.000 & $\mathrm{Rp}$ & 300.000 \\
\hline & & Biaya Pencetakan Soal & $\mathrm{Rp}$ & 5.000 & $\mathrm{Rp}$ & 1.500 .000 & $\mathrm{Rp}$ & 9.000 .000 \\
\hline & & Biaya Pencetakan Absen Siswa & $\mathrm{Rp}$ & 2.000 & $\mathrm{Rp}$ & 18.750 & $\mathrm{Rp}$ & 112.500 \\
\hline & & Biaya Pencetakan Absen Pengawas & $\mathrm{Rp}$ & 2.000 & $\mathrm{Rp}$ & 2.000 & $\mathrm{Rp}$ & 12.000 \\
\hline & & Biaya Kosumsi Pengawas & $\mathrm{Rp}$ & 10.000 & Rp & 93.750 & Rp & 562.500 \\
\hline & & Biaya Pencetakan No Ujian + Ruangan & $\mathrm{Rp}$ & 500 & $\mathrm{Rp}$ & 150.000 & $\mathrm{Rp}$ & 900.000 \\
\hline & & Biaya Pembuatan Kartu Peserta Ujian & $\mathrm{Rp}$ & 2.500 & $\mathrm{Rp}$ & 750.000 & $\mathrm{Rp}$ & 4.500 .000 \\
\hline 3 & Raport & Biaya Pence takan Raport & $\mathrm{Rp}$ & 60.000 & $\mathrm{Rp}$ & 8.000 .000 & $\mathrm{Rp}$ & 18.000 .000 \\
\hline \multicolumn{7}{|c|}{ Total } & Rp & 33.537 .000 \\
\hline
\end{tabular}

Untuk menghitung biaya operasional pembangunan sekolah ini menggunakan cara sebagai berikut : 
Jurnal Riset Sistem Informasi Dan Teknik Informatika (JURASIK)

Volume 5 Nomor 1 Februari, pp 68-76

ISSN: 2527-5771/EISSN: 2549-7839

http://tunasbangsa.ac.id/ejurnal/index.php/jurasik

Biaya total $=\sum(\mathrm{Tf} x \mathrm{Jk})$

Dimana Tf merupakan tarif biaya kegiatan dan Jk adalah jumlah unit (jika kegiatan tersebut berhubungan dengan siswa, misalnya pencetakan soal Jk merupakan jumlah siswa). Langkah berikutnya adalah otomasi produksi pesanan pada tabel pesanan dengan menginputkan kode produk pada Tabel Hasil Proses Otomasi, sehingga muncul detail data secara otomatis. Berikut adalah Tabel Hasil Proses Otomasi

Tabel 7. Hasil Otomasi

\begin{tabular}{|c|c|c|c|c|c|c|c|c|c|c|c|c|c|}
\hline \multirow{2}{*}{$\begin{array}{c}\text { NIS } \\
19001\end{array}$} & \multirow{2}{*}{$\begin{array}{c}\text { Nama Siswa } \\
\text { Siswa }\end{array}$} & \multicolumn{2}{|c|}{$\begin{array}{c}\text { Biaya Sarana } \\
\text { Prasarana }\end{array}$} & \multicolumn{2}{|c|}{$\begin{array}{c}\text { Biaya } \\
\text { Bangunan }\end{array}$} & \multicolumn{2}{|c|}{$\begin{array}{c}\text { Biaya Buku } \\
\text { Pelajaran }\end{array}$} & \multirow{2}{*}{$\begin{array}{l}\text { Biaya Guru } \\
\text { Rp204.583 }\end{array}$} & \multicolumn{2}{|c|}{$\begin{array}{c}\text { Biaya } \\
\text { Pendidikan }\end{array}$} & \multicolumn{2}{|c|}{$\begin{array}{c}\text { Biaya } \\
\text { Operasional }\end{array}$} & \multirow{2}{*}{$\begin{array}{l}\text { Jangka } \\
\text { Waktu } \\
3 \text { tahun }\end{array}$} \\
\hline & & $\mathrm{Rp}$ & 24.351 & $\mathrm{Rp}$ & 171.354 & $\mathrm{Rp}$ & 183.333 & & $\mathrm{Rp}$ & 3.446 & $R p$ & 18.632 & \\
\hline 19002 & Siswa & $R p$ & 24.351 & $\mathrm{Rp}$ & 171.354 & $\mathrm{Rp}$ & 183.333 & Rp204.583 & $\mathrm{Rp}$ & 3.446 & $\mathrm{Rp}$ & 18.632 & 3 tahun \\
\hline 19003 & Siswa & $R p$ & 24.351 & $\mathrm{Rp}$ & 171.354 & $\mathrm{Rp}$ & 183.333 & Rp204.583 & $\mathrm{Rp}$ & 3.446 & $\mathrm{Rp}$ & 18.632 & 3 tahun \\
\hline 19004 & Siswa & $\mathrm{Rp}$ & 24.351 & $\mathrm{Rp}$ & 171.354 & $\mathrm{Rp}$ & 183.333 & Rp204.583 & $\mathrm{Rp}$ & 3.446 & $\mathrm{Rp}$ & 18.632 & 3 tahun \\
\hline 19005 & Siswa & $R p$ & 24.351 & $\mathrm{Rp}$ & 171.354 & $\mathrm{Rp}$ & 183.333 & Rp204.583 & $\mathrm{Rp}$ & 3.446 & $\mathrm{Rp}$ & 18.632 & 3 tahun \\
\hline 19006 & Siswa & $\mathrm{Rp}$ & 24.351 & $\mathrm{Rp}$ & 171.354 & $\mathrm{Rp}$ & 183.333 & Rp204.583 & $\mathrm{Rp}$ & 3.446 & $\mathrm{Rp}$ & 18.632 & 3 tahun \\
\hline 19007 & Siswa & $\mathrm{Rp}$ & 24.351 & $\mathrm{Rp}$ & 171.354 & $\mathrm{Rp}$ & 183.333 & Rp204.583 & $\mathrm{Rp}$ & 3.446 & $\mathrm{Rp}$ & 18.632 & 3 tahun \\
\hline 19008 & Siswa & $\mathrm{Rp}$ & 24.351 & $\mathrm{Rp}$ & 171.354 & $\mathrm{Rp}$ & 183.333 & Rp204.583 & $\mathrm{Rp}$ & 3.446 & $\mathrm{Rp}$ & 18.632 & 3 tahun \\
\hline 19009 & Siswa & $\mathrm{Rp}$ & 24.351 & $\mathrm{Rp}$ & 171.354 & $\mathrm{Rp}$ & 183.333 & Rp204.583 & $\mathrm{Rp}$ & 3.446 & $\mathrm{Rp}$ & 18.632 & 3 tahun \\
\hline 19010 & Siswa & $\mathrm{Rp}$ & 24.351 & $\mathrm{Rp}$ & 171.354 & $\mathrm{Rp}$ & 183.333 & Rp204.583 & $\mathrm{Rp}$ & 3.446 & $\mathrm{Rp}$ & 18.632 & 3 tahun \\
\hline$\ldots$ & $\ldots$ & & $\ldots$ & & $\ldots$ & & $\ldots$ & $\ldots$ & & ... & & $\ldots$ & $\ldots$ \\
\hline$\ldots$ & $\ldots$ & & $\ldots$ & & $\ldots$ & & $\ldots$ & $\cdots$ & & ... & & $\ldots$ & $\ldots$ \\
\hline
\end{tabular}

Setelah didapatkan hasil otomasi kemudian dicari biaya setiap produk (siswa) per bulan. Dengan menggunakan rumus sebagai berikut:

$$
\text { Biaya }=\sum \frac{\text { Total Biaya Per Unit }}{\text { Batas pakai Unit x Jumlah Siswa }}
$$

Tabel 8. Biaya SPP setiap siswa

\begin{tabular}{|r|l|lr|}
\hline No & Nama & \multicolumn{2}{|c|}{ Biaya Per Murid } \\
\hline 1 & Biaya Sarpras & $\mathrm{Rp}$ & 24.351 \\
\hline 2 & Biaya Bangunan & $\mathrm{Rp}$ & 171.354 \\
\hline 3 & Biaya Buku Pelajaran & $\mathrm{Rp}$ & 183.333 \\
\hline 4 & Biaya Guru & $\mathrm{Rp}$ & 204.583 \\
\hline 5 & Biaya Pendidikan & $\mathrm{Rp}$ & 3.474 \\
\hline 6 & Biaya Operasional Tambahan Sekolah & $\mathrm{Rp}$ & 18.632 \\
\hline \multicolumn{2}{|c}{ Total Biaya } & $\mathbf{R p}$ & $\mathbf{6 0 5 . 7 2 8}$ \\
\hline
\end{tabular}

Kemudian dilakukan percobaan dengan mengubah jumlah lulusan dan jumlah siswa untuk mengetahui pergerakan nilai biaya per produk (siswa) per bulannya 
Jurnal Riset Sistem Informasi Dan Teknik Informatika (JURASIK)

Volume 5 Nomor 1 Februari, pp 68-76

ISSN: 2527-5771/EISSN: 2549-7839

http://tunasbangsa.ac.id/ejurnal/index.php/jurasik

Tabel 9. Percobaan dengan merubah target lulusan

\begin{tabular}{|c|c|c|c|c|}
\hline No & Target Lulusan & Jumlah Siswa & \multicolumn{2}{|c|}{ Biaya Pendidikan perSiswa } \\
\hline 1 & 20 & 60 & Rp & 887.474 \\
\hline 2 & 50 & 150 & Rp & 675.477 \\
\hline 3 & 75 & 225 & Rp & 628.774 \\
\hline 4 & 100 & 300 & Rp & 605.699 \\
\hline 5 & 125 & 375 & $\mathrm{Rp}$ & 592.076 \\
\hline 6 & 150 & 450 & $\mathrm{Rp}$ & 583.179 \\
\hline 7 & 175 & 525 & Rp & 576.983 \\
\hline 8 & 176 & 528 & $\mathrm{Rp}$ & 692.704 \\
\hline 9 & 185 & 555 & $\mathrm{Rp}$ & 690.913 \\
\hline 10 & 200 & 600 & Rp & 688.327 \\
\hline 11 & 250 & 750 & $\mathrm{Rp}$ & 682.236 \\
\hline 12 & 280 & 840 & Rp & 679.815 \\
\hline 13 & 300 & 900 & Rp & 678.544 \\
\hline 14 & 350 & 1050 & Rp & 676.225 \\
\hline
\end{tabular}

Sehingga didapatkan Grafik seperti ini :

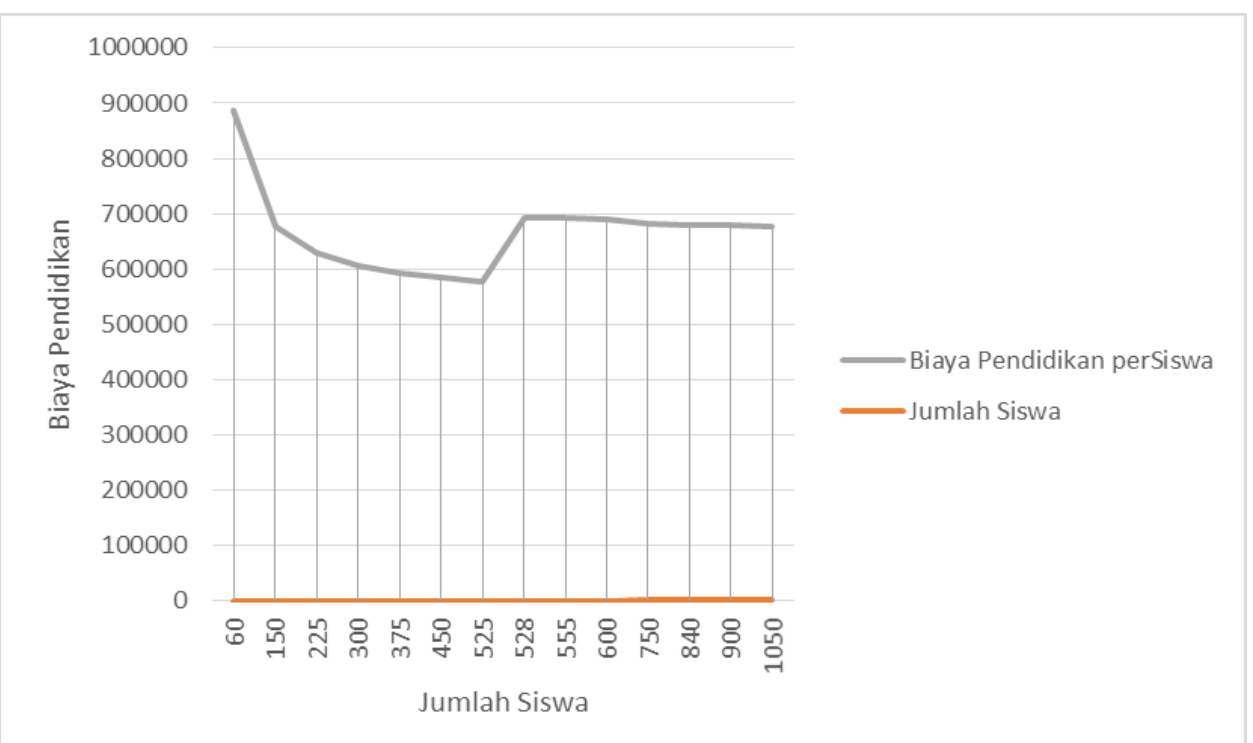

Gambar 1. Grafik perbandingan jumlah siswa dengan biaya produksi

\section{SIMPULAN}

Pada penelitian ini dibahas mengenai otomasi perencanaan produksi pada sekolah. Letak otomasinya adalah kita melakukan perhitungan biaya dalam perencanaan produksi menggunakan Excel dengan parameternya adalah jumlah siswa. Dalam percobaan yang kita lakukan dapat dilihat pada gambar 1. Digambar tersebut dapat dilihat bahwa tidak menjamin semakin banyak siswa akan menurunkan atau memperingan biaya produksi. Ada di angka tertentu yang menyebabkan biaya produksi itu meningkat. Sehingga grafik tersebut dapat dirumuskan sebagai berikut: 


$$
\mathrm{f}(\mathrm{x})=\left\{\begin{array}{l}
\mathrm{a}<=\mathrm{x}<=\mathrm{b} \\
\mathrm{b}<=\mathrm{x}<=\mathrm{c} \\
\mathrm{c}<=\mathrm{x}<=\mathrm{d}
\end{array}\right.
$$

Dimana $\mathbf{x}$ adalah jumlah siswa, $\mathbf{a}$ dan $\mathbf{b}$ adalah variabel bebas.

Dengan demikian, semua orang mengetahui bawasannya untuk melakukan produksi sekolah membutuhkan sebuah perencanaan produksi. Untuk sekolah di Indonesia masih banyak sebagian sekolah yang masih belum membuat perencanaan produksi (RAB) guna membangun sekolah yang sesuai standarisasi di Negara Indonesia. Untuk membuat perencanaan produksi dapat dilakukan dengan menggunakan Teknik ABC. Teknik ABC (Activity-Based Costing) adalah sistem akumulasi biaya dan pembebanan biaya ke produk dengan menggunakan berbagai cost driver, dilakukan dengan menelusuri biaya dari aktivitas dan setelah itu menelusuri biaya dari aktivitas ke produk.

Perencanaan produksi merupakan kegiatan perencanaan yang dilakukan sebelum melakukan kegiatan produksi dengan mempertimbangkan jumlah permintaan berdasarkan sumber daya yang dimiliki oleh perusahaan. Metode yang digunakan pada proses produksi dilakukan secara deskriptif dengan 5 langkah.

\section{DAFTAR PUSTAKA}

[1] Yaqin, M.A., Pusaka, A., Najib, A., dan Setiawan, P., "Otomasi Perencanaan Produksi pada Permainan Hay Day Menggunakan Metode Material Requirement Planning (MRP)", SENIATI, vol. 5, pp 65 - 72, February 2019.

[2] Alfaidah, F.M., "Integrasi Sistem Informasi Perencanaan Produksi Pada Enterprise Resource Planning Pondok Pesantren Tipe D Menggunakan Service Oriented Architecture", Undergraduate thesis, Universitas Islam Negeri Maulana Malik Ibrahim, Maret 2017. Diakses dari: http://etheses.uin-malang.ac.id/5842/

[3] Purnomo, A., "Perencanaan Produksi Dan Pengendalian Persediaan Bahan Baku Pada Pengrajin Tahu Dan Tempe "IM" Cibogo Bandung", Jurnal Logistik Bisnis, vol. 1, no. 1, pp 97 - 117, May 2010.

[4] Chirzun, A., Nurhasanah, N., dan Utami, T.A., "Rancangan Perencanaan Produksi Jenis Produk Make To Order dengan Pendekatan Simulasi Sistem Dinamik", AL-AZHAR INDONESIA SERI SAINS DAN TEKNOLOGI, vol. 3, no. 3, pp 113 - 119, Maret 2016.

[5] Suwirmayanti, N.L.G.P., dan Yudiastra, P.P., "Penerapan Metode Activity Based Costing Untuk Penentuan Harga Pokok Produksi”, Jurnal Sistem dan Informatika, vol. 12, no. 2, pp $34-44$, Mei 2018.

[6] Mandala, H., Rachmat, H., dan Atmaja, D.S.E., "Perancangan Sistem Otomatisasi Penggilingan Teh Hitam Orthodoks Menggunakan Pengendali PLC Siemens S7 1200 dan Supervisory Control and Data Acquisition (SCADA) di PT. Perkebunan Nusantara VIII Rancabali", e-Proceeding of Engineering, vol. 2, no. 1, pp 990 - 997, April 2015. 